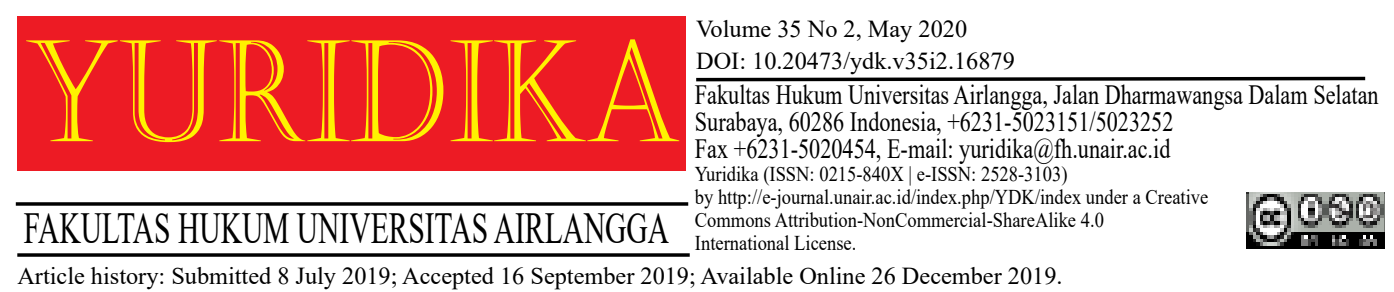

\title{
Legal Protection for Justice Collaborators in Indonesia's Criminal Judiciary System
}

\author{
Hidayatullah \\ Hidayat4562@gmail.com \\ General Attorney of Republic Indonesia
}

\begin{abstract}
One way to assist law enforces to prevent and combat crime is to involve justice collaborators. Justice collaborators are crucial in assisting law enforcers to expose perpetrators of organized crime as well as transnational crimes. The lack of a legal regime that provides rights to a justice collaborator will impact the interest of a person to become a justice collaborator. Legal protection for justice collaborators must also include protection to his/her family both physically and psychologically. One method of appreciation that can be given to justice collaborators is through the special treatment of criminal offences. One form of special treatment in regards to criminal cases involving justice collaborators within the criminal judiciary may utilize the plea bargaining approach as a method of legal protection towards justice collaborators. To make more efficient the process of determining criminal sanctions to justice collaborators will contribute to the legal certainties owed to justice collaborates as a rightful reward of their contribution in extraordinary crimes. The criminal judicial system that utilized the plea bargaining approach for justice collaborators has the advantage of the absence of criminal examinations.
\end{abstract}

Keywords: Legal Protection; Justice Collaborator; Criminal Judiciary System.

\section{Introduction}

The court as one of the institutions of modern law is a place provided by the State to settle disputes. ${ }^{1}$ One of the methods to assist law enforces in preventing and combating crime is to involve justice collaborators. Justice collaborators are crucial in helping law enforcers expose perpetrators in organized crimes as well as transnational crimes, as it is substantially difficult for law enforces to conduct law enforcement in cases of organized crimes without the involvement or assistance

\footnotetext{
1 Agus Priono, 'Penerapan Teori Penafsiran Hukum Oleh Hakim Sebagai Upaya Perlindungan Hukum Terhadap Notaris (Studi Atas Putusan Hakim Terhadap Tindak Pidana Pemalsuan Akta Otentik)' (2017) v Jurnal Pasca Sarjana Hukum UNS.[119].
} 
from witnesses who are willing to cooperate. A witness that is willing to cooperate with law enforcers will provide great impact in the effort to combat crimes through the criminal justice system. In cases of extraordinary crimes such as corruption, drugs, terrorism, and money laundering, the witness can work together with law enforces to ensure that such crimes will be resolved in the most efficient way. This is especially true for cases involving drugs, whereby law enforcers are often in need of cooperation with relevant witnesses. Law enforcers still find difficulties in obtaining the main perpetrators in cases involving the abuse and distribution of illegal narcotics in Indonesia. There have been numerous landmark cases on this issue but none of which have been able to identify the producer of these illegal drugs, merely capturing the distributor of these drugs.

The involvement of justice collaborators in combating organized crimes as well as serious and transnational crimes have become inevitable. The lack of legal clarity in regulating justice collaborators will prevent less incentive for perpetrators to abide to law enforcers. Without the existence of some form of insurance for justice collaborators, perpetrators that have obliged to cooperate with law enforcers will be placed at a substantial disadvantage and possible danger. The lack of rights provided to witnesses and victims will give rise to the belief that these witnesses and victims are not provided with legal protection for their participation in the judicial process. ${ }^{2}$

For example, a member of the DPR from the political party PDIP, Agus Tjondro Prayitno that has been categorized as justice collaborators in the case concerning the appointment of Senior Deputy of the Federal Bank of Indonesia (BI). Agus reported the existence of bribes in the election for the new BI Senior Deputy and returned the $\operatorname{Rp} 500.000 .000$ (five hundred million) bribe to the State after its disclosure to the public. One example which evidences the lack of regulation governing justice collaborators can be seen in the case of Agus Tjondro Prayitno who agreed to become a justice collaborator but is provided with the same criminal treatment as

2 Supriadi Widodo Eddyono, Perlindungan Saksi Dan Korban: Catatan Atas Pengalaman Pengadilan HAM Ad Hoc Kasus Pelanggaran HAM Berat Di Timor Timur (ELSAM 2005).[3]. 
the other perpetrators. ${ }^{3}$ In the corruption case concerning the Electronic National Identification Card (also known as E-KTP) that presented an estimated loss of Rp 2.300.000.000.000 (two trillion and three hundred trillion rupiahs) to the State, the National Commission for the Eradication of Corruption (commonly known as KPK) has convicted Irman and Sugoharto as justice collaborators. However, the Judges within that case upheld a different opinion. The lack of standardization on the status of justice collaborators and the lack of legal regime that creates clear participative possibilities for justice collaborators to assist combating extraordinary crimes is a far-reached goal. Furthermore, current Indonesian legislations has yet to regulate the criteria for perpetrators of an extraordinary crime. This lack of regulation highly impacts the success rates of the involvement of justice collaborators in combating and preventing organized crimes. Establishing a criteria for main perpetrators is crucial, as it may create different interpretations on the status of justice collaborators by public prosecutors and the judges within the a criminal case.

The lack of regulations or legal regime regarding the rights that is given to a justice collaborator will impact the willingness of someone to cooperate and become a justice collaborator in a criminal case. This problem is evident in cases of corruption can demage demociacy, ${ }^{4}$ such as that involving Muhammad Nazaruddin who was granted the status of justice collaborator by the KPK even when he is considered to be one of the main perpetrators of the case. KPK puts aside the concept of justice collaborators in existing foreign legislations and international conventions, that exempts main perpetrators from being granted a justice collaborator status. This creates an urgency in drafting a legislation that regulates and protects the rights of justice collaborators in the Indonesian criminal law system. Furthermore, providing a perpetrator with the status of justice collaborators must be based on

3 Koran Sindo, 'Hukuman Untuk Agus Condro Disesalkan' (Indonesia Corruptionn Watch, 2011) $<$ https://antikorupsi.org/id/news/hukuman-untuk-agus-condro-disesalkan> accessed $27 \mathrm{Au}$ gust 2019.

4 Bintara Sura Priambada, 'Eksistensi KPK Dalam Memberantas Tindak Pidana Korupsi' (2017) VI Lex Crimen <https://media.neliti.com/media/publications/170253-ID-eksistensi-kpk-dalam-memberantas-tindak.pdf $>$.[62]. 
clear and concrete criteria, keeping in mind that in most cases perpetrators would file to become justice collaborators just to avoid criminal charges. Based on the introduction above, the discussion question that will be addressed in this paper in the legal protection for justice collaborators in Indonesia's criminal legal system.

\section{Existence of Justice Collaborators in Indonesia}

Criminal law enforcement in Indonesia's judicial system is a legal issue that is often highlighted by the public, largely due to the fact that law enforcement in Indonesia has yet to reflect a sense of justice and legal certainty. Law enforcers often act discriminately in conducting their official functions, which worsens the image of law enforcement that is viewed as cherry-picking. The irony in Indonesia's legal enforcement system has reached a concerning stage whereby it creates a mindset to the public that law enforcers are sharp to those below it and $d u l l$ to those above it. The existence of this mindset is caused by law enforcers (police, prosecutor and judges) that act against social justice, such as being discriminative towards criminal suspects.

Under the people's view, these discriminative judgements are evidenced by the existence of transactional relationships between law enforcers and the parties of a certain criminal case. The existence of these transactional relationships provide a sense of injustice within the people, as well as provide possible biases by law enforcement towards a specific side of the disputing parties. This results in an unjust criminal proceeding.

Ideally, every criminal case must consistently uphold the three purposes of justice which are legal certainty, legal use and justice. Muladi elaborates that law enforcement must be interpreted in a 3 (three) skeleton process, that is the concept of law enforcement that is absolute and demands that all values pertained within a certain legal norm be enforced without exception. However, this is particularly difficult to execute as there exist limitations in procedural law which protects the interests of individuals as well as the actual concept of law enforcement that arises after the existence of discretion in law enforcement due to positive limitations which relates to administrative prerequisites, the quality of individuals, the quality of existing legislations and the lack of public participation. 
The lack of public participation in law enforcement in general, stems from the law of trust the public holds towards law enforcers. One of the reasons for this lack of trust is a result of lengthy legal processes that often disappoint the public. Furthermore, there exists no certainty that the people who have agreed to participate will gain legal protection from law enforcers. Without the existence of these legal protections, the people will never be willing to participate in law enforcement as it might merely present them with loss and disappointment. The lack of legal protection towards the people's participation as a witness or victims in criminal cases is sometimes not only due to the fault of law enforcers. Current regulations on criminal procedural law, which is the KUHAP, does often provide legal protection for the interests of the suspect and even the convicted. This protection for the interests of the witness as well as the victims, even when regulated under the Act on the Protection of Witnesses and Victims, are often disregarded in law enforcement.

This disregard to these rules will arise difficulties in law enforcement as the people would remain passive in criminal disputes and as a result lead to an unsolved case. In reality, law enforcers need public participation in combating criminal cases especially cases of organized crimes. Justice collaborators also face this disregard to their rights which results in the ineffective participation of justice collaborators in cases of organized crime. The involvement of justice collaborators are often seen in corruption cases handled by the KPK and most justice collaborators are merely participating to avoid severe punishment not because of a sense of guilt. This can be proven by the difference or disparity in criminal charges that is filed by the KPK for suspects that request to be called justice collaborators and those who did ask to be called justice collaborators.

Based on Article 1 of the Act on the Protection of Witnesses and Victims, a perpetrator can be seen as suspects and convicts that have worked together with law enforcers to reveal a criminal act in a criminal case. Whereas a person who reports these offences are individuals who provide information and statements to law enforcers regarding a certain criminal act that is currently happening or is expected to happen. These different definitions can be found the Regulations 
established by the Ministry of Law and Human Rights of the Republic of Indonesia, the Judges of the Republic of Indonesia and the National Police of the Republic of Indonesia, the Commission for the Eradication of Corruption in Indonesia, the Head of the Witness and Victims Protection Agency of the Republic of Indonesia Number : M.HH-11.HM.03.02.th.2011 Number : PER-045/A/JA/12/2011 Nomor : 1 of the Year 2011 Number : KEPB-02/01-55/12/2011 Nomor : 4 of the Year 2011 regarding the Protection for Witnesses and perpetrators that has agreed to cooperate (hereinafter stated as "Combined Regulations") that determines that the reporting witness is a person that sees, hears and experiences a certain criminal act and reports their suspicions regarding that certain criminal act to the authorities for the purpose of filing a charge under existing regulations. Whereas the perpetrator witness that has agreed to cooperate is a witness that is also a perpetrator to a certain criminal act that has agreed to assist legal enforcers to reveal the existence of a crime that will occur in order to return the assets and the result back to the State, through providing information to legal enforcers as well as presenting a testimony in a judicial proceeding.

Justice collaborators in the criminal justice system sits in a dual-position, not just as a perpetrator that is supposed to undergo several convictions as a consequence of their wrongful conduct, but also a witness that benefits legal enforcers as he/she is willing to cooperate in these proceedings. According to Article 34A paragraph (1) letter a of PP Number 99 of the Year 2012, justice collaborators in narcotic cases, corruption cases, grave human rights violations cases as well as transnational crimes must receive reduced punishments. The additional requirements to file for remissions must burden justice collaborators as not all convicts can be classified as justice collaborators. Article 34A paragraph (3) strengthens, that the will to cooperate must be established through a written statement and established by a law enforcement body. The requirement to obtain that establishment also presents its own challenges to public administrative bodies (Lapas) in filing the request for remission to the Ministry of Law and Human Rights. Article 34 of PP number 99 of the Year 2012 regulates that the agreement of cooperation must be presented in 
a written form in order to combat criminal cases, have paid in full all the necessary fines and settlement pay in accordance with the decision of the corruption court, and have completed a de-radicalization program which states the person's loyalty to the State as well as non-repetition. ${ }^{5}$

Justice collaborators are a crucial instrument in criminal law enforcement that can be utilized to combat organized crime. There exist several instruments under international law that can be used as the guidelines to regulate justice collaborators such as the following:

a. United Nations Convention against Corruption (hereinafter "UNCAC") that has been ratified by Indonesia through Act Number 7 of the Year 2006 regarding the ratification of United Nations Convention Against Corruption 2003 (State Gazette of the Republic of Indonesia published in the Year 2006 Number 32, State Gazette of the Republic of Indonesia Number 4620). Justice collaborators in the UNCAC is regulated under Article 37 paragraph (2) and (3), falls under the special treatment for those involved in corruption cases that are willing to cooperate with legal enforcers in identifying other perpetrators. Article 37 paragraph (2) of the UNCAC establishes that each State Party has an obligation to consider the possibilities of each case, reduce sentence from a perpetrator that is willing to substantially cooperate during the investigation process or the conviction of a crime, in accordance with the provisions established by this Convention. There also exists Article 37 paragraph (3) of the UNCAC which establishes that each State Party has an obligation to consider the circumstances based on the basic principles of its national law to provide "immunity from charges" for individuals who have substantially cooperated during the investigation or prosecution process (justice collaborator) of a criminal crime covered by this Convention.

b. Council of Europe Committee of Ministers Recommendations 2005 (on Witness and Collaborator of Justice). On the Council of Europe Committee of Minister

\footnotetext{
5 Rosmiyati Dewi Kandi, 'Syarat "Justice Collaborator” Jadi Kendala Dapatkan Remisi' (CNN Indonesia, 2016) <https://www.cnnindonesia.com/nasional/20160427193723-12-127069/ syarat-justice-collaborator-jadi-kendala-dapatkan-remisi?> accessed 30 August 2019.
} 
Recommendations 2005 regulates that each individual that is faced with criminal charges or is proven guilty due to its participation in a criminal syndicate or other forms of criminal organizations in any shape or form, or within organized crimes, but has agreed to cooperate with the authorities of the criminal justice system, especially through providing testimonies regarding such criminal syndicates or criminal organizations or regarding any organized crime activities or other grave criminal violations.

c. United Nations Convention Against Transnational Organized Crime (hereinafter "UNTOC") that has been ratified by Indonesia through Act Number 5 of the Year 2009 regarding the Ratification of the United Nations Convention Against Transnational Organized Crime or UNTOC. Justice collaborators within the UNTOC is regulated under Article 26 paragraph (2) and (3) that is in principle a special treatment obligation for witnesses that have worked together with law enforcers in exposing organized crime. Article 26 paragraph (2) establishes that each State Party must consider to provide the possibility, for certain cases, of a reduced sentence for suspects that have agreed to substantially cooperate with during the investigation or prosecuting process of a crime that is covered by the present Convention. There also exists Article 26 paragraph (3) which establishes that each State Party shall consider to provide the possibility for, in accordance with the principles of its domestic legal system, provide immunity from charges to a person that have provided substantial cooperation during an investigation or charge of an offence covered by the present Convention.

According to Article 24 of the UNTOC, State Parties have to conduct several adequate efforts to provide effective protection from the retaliation or intimidation towards witnesses that are willing to provide testimonies in cases involving organized crimes. These efforts can include physical protection, relocation and secrecy as well as the limitation of the disclosure of personal identities and witness location and the implementation of burden of proof regulations which allow testimonies to assert the validity of the evidence presented.

Based on the aforementioned provisions entailed in Article 37 of the UNCAC and Article 26 of the UNTOC, there exists several forms of awards that can be given 
to a witness that has cooperated with law enforcers. The forms of awards that can be given are of the following:

a. To reduce the sentence for a person willing to cooperate substantially during the investigation as well as the trial process of a charge for organized crime. The reduction of a sentence remains as the most rational award for justice collaborators, keeping in mind that these individual still have to be held responsible for its actions due to a need for justice in the community. Furthermore, this remains as the appropriate policy to avoid the misuse of justice collaborators as the base of an unethical transactional relationship between the perpetrators and the law enforcers. This point is considered due to the fact that law enforcers are often easily persuaded by financial gain and are often unprofessional. Reducing criminal sanctions are often provided to justice collaborators but some States also opt for clemency or immunity.

b. Providing immunity from charges to justice collaborators. Immunity from charges is the highest form of award for justice collaborators. The impunity of the prosecution is of course only given in certain circumstances to safeguard the safety of justice collaborators and their families that might be severely threatened if their identities are revealed to the public through criminal justice mechanisms. Such conditions are very likely to occur if the crime committed involves a mafia such as the case for countries such as Mexico. As for Indonesia, this type of immunity from prosecution for collaborating witnesses has yet to be given, considering that the human resources of law enforcement officials in Indonesia tend to be unprofessional or abuse their authority.

Based on the study above, it can be concluded that several international conventions have elaborate and regulate justice collaborators as instruments in criminal law enforcement that can be used by law enforcement officials in revealing an organized crime. Rewards is an important component for justice collaborators because it has helped law enforcement officials by taking or placing risks to themselves and their families. Based on several international conventions above, there are several alternative rewards that can be given to justice collaborators, 
namely providing no criminal prosecution against justice collaborators; the providing of immunity to punishment; reducing criminal sentence and the existence of guarantees that benefit the defendant when they appear before the criminal justice process, for example: outside detainees, early release, parole. In addition, it is also necessary to develop a special program for the protection of Justice collaborators, the aim of which is to provide protection from serious threats from people having special interests in the case.

The legal basis of witnesses cooperating is regulated in Article 10 of the Law on Witness and Victim Protection which principally determines Witnesses, Victims, Perpetrators, and/or Reporting Parties cannot be prosecuted, both in criminal and civil proceedings, for testimonies and/or reports that will, are being, or has been given, unless the testimony or report is not given in good faith. Pursuant to Article 10 of the aforementioned Witness and Victim Protection Law, there is a guarantee of impunity for witnesses who collaborate on criminal and civil charges by providing testimonies given in good faith. The impunity is related to reports or claims made by the parties mentioned or related to the information provided by the witnesses of the collaborating perpetrators. The immunity from prosecution for criminal offenses committed is not regulated in Indonesia so that the form of appreciation for the witnesses who collaborated was only reducing sentences and protection from threats to their safety and family.

In addition to legal immunity as referred to in Article 10 of the Witness and Victim Protection Act, specifically for witnesses who are cooperating in accordance with the provisions of Article 10A of the Witness and Victim Protection Act, special treatment can be given in the process of examination and appreciation for the testimony given. Appreciation can be given in the form of: a. the separation of places of detention or places of criminal conduct between Acting Witnesses who cooperate with suspects, defendants, and/or convicts whose criminal offenses are revealed, b. the separation of files between the files of Acting Witnesses in collaboration with the files of suspects and defendants in the investigation process, and the prosecution of criminal acts which they disclose and / or provide testimony 
before the court without face to face with the defendants whose criminal acts are revealed. In addition to special treatment in the examination and detention process of collaborating witnesses, collaborating witnesses may also be given awards in the form of reduced criminal convictions or conditional release, additional remissions, and other prisoners' rights in accordance with statutory provisions for Acting Witnesses who are in prison according to the provision of Article 10A paragraph (3) of the Witness and Victim Protection Law.

Justice collaborator protection arrangements in Indonesia were formulated after Indonesia's ratification of the UNCAC and UNTOC. However, not all special treatment of justice collaborators in the two conventions was adopted in the Law on Witness and Victim Protection. As stated earlier in UNCAC and UNTOC, special treatment that can be given to witnesses in collaboration is the reduction of punishment and immunity from prosecution. Whereas in the Witness and Victim Protection Act the award is in the form of criminal relief or granting parole, additional remissions, and other prisoners' rights for Acting Witnesses who are prisoners. In practice, the protection of justice collaborators in Indonesia still refers to the provisions in SEMA 4 of 2011, even though there are differences with the Witness and Victim Protection Act. The criteria for granting justice collaborator status as referred to in SEMA 4 of 2011 are:

a. Those involved are one of the perpetrators in a certain criminal act, such as corruption, terrorism, narcotics, money laundering, human trafficking, even other crimes relating to organized crime, acknowledge the wrongful act committed, is not the main suspect of the crime and provide a testimony as a witness during the trial process.

b. Public prosecutor in its charge will state that the person involved has provided facts and evidence that are significant to the case. Thus, the investigator and public prosecutor is able to uncover the crimes mentioned effectively, discover other relating suspects which holds more significant roles in the case and/or reverse/return the assets or actions of a criminal act.

c. Due to this person's assistance, towards other acting witnesses that have 
cooperated, the judge in providing a judgement can consider all of the legal facts and provide probation with requirements and/or provide a judgement that provides less jail-time. In providing such special treatment that is considered the reducing of criminal convictions, the judge must also consider elements of social justice.

The basis for consideration of the Supreme Court in issuing SEMA 4 of 2011 is the existence of certain serious crimes such as corruption, terrorism, narcotics, money laundering, human trafficking, and other organized criminal acts, which have posed serious problems and threats to stability and public safety. So it requires public participation in uncovering the crime. Increasing public participation can only be done if there exists a conducive climate created through legal protection and special treatment to those who know, report and/or find something that can help law enforcement officials uncover and deal with organized crime effectively.

In principle, the Supreme Court considers justice collaborator to be one of the reasons that can be used to deviate the minimum criminal provisions specifically in the legislation. However, deviations from the minimum criminal provisions specifically in the statutory regulations as a form of respect for justice collaborators, will be difficult to apply if the legal basis used is SEMA 4 of 2011. The public prosecutor will certainly take legal action against the decision because it is considered contrary to existing laws and regulations. This is one of the reasons that the provisions of justice collaborator must be regulated in the law so that law enforcement officials have a standardized view in providing legal protection to justice collaborators.

Criminal imprisonment that is equivalent to the lightest imprisonment requirement among other defendants who was proven guilty in the case in question, is a form of justified awards given to justice collaborators. The reduction in punishment for justice collaborators in criminal justice practices is realized through the conviction of the mildest prison sentence among other defendants who were proven guilty in the case concerning. The practice of imprisonment for lower justice collaborators compared to other defendants has often been applied in several court decisions but there are also justice collaborators whose convictions are the same 
as other defendants. The verdict that convicted the same criminal justice justice collaborator with the other defendants is legally contrary to SEMA 4 of 2011 or the LPSK Law but does not cause any legal consequences because the regulation of justice collaborator in Indonesia is still half-hearted in spirit.

Provisions in SEMA 4 of 2011 tend to cause new legal problems in the legal protection of justice collaborators because one of the requirements in requesting to become a justice collaborator is that the person must not be the main perpetrator of the crimes invoked. This requirements is an appropriate and very logical requirement, but the problem is that SEMA 4 of 2011 and other laws and regulations do not contain this criteria. The lack of regulation regarding the criteria of the main actor causes legal uncertainty which can be proven in several cases whereby the public prosecutor believes the defendant is a witness of the collaborating actor, but the panel of judges examining the case states that the defendant is the main actor so that he is not entitled to special treatment regulated in SEMA 4 of 2011 as well as the Law on Witness and Victim Protection.

The Joint Regulation also regulates the special treatment of witnesses who collaborate. The Joint Regulation determines that the witness who cooperates is a witness who is also a criminal offender who is willing to assist law enforcement officials to uncover a criminal act or the occurrence of a criminal act to return assets or proceeds of a crime to the state by providing information to the authorities law enforcement and provide testimony in the judicial process. The serious and/ or organized criminal acts referred to in this Joint Regulation are criminal acts of corruption, gross violations of human rights, narcotics/psychotropic, terrorism, money laundering, human trafficking, forestry and/or other criminal acts that can cause danger and threatens the safety of the wider community. Some of the crimes mentioned in the definition of serious crimes in this Joint Regulation are carried out by people who have intelligence, financial or power capabilities so that they tend to pose a threat to justice collaborators and their families so that the state through law enforcement officials must provide certainty of their status and the position of witnesses who are willing to collaborate. Based on the provisions of Article 4 
of the Joint Regulations, the conditions for obtaining protection as witnesses of cooperating actors are:

a. Criminal acts that have been uncovered such as serious crimes and/or organized crimes;

b. Provide significant statements that are relevant and reliable to uncover a serious crimes and/or organized crimes;

c. No the main perpetrator of the acts uncovered;

d. The willingness to return an amount of assets that is obtained from the criminal acts invoked, provided by an official written statement; and

e. The existence of a real threat or concern of threat, pressure, both physically and/ or psychologically towards the individual that is cooperating or his/her family provided that the crime is uncovered in its truest light.

The special treatment for witnesses who collaborate in this Joint Regulation is the same as the special treatment given to collaborating witnesses who are regulated in the Witness and Victim Protection Act, but there is no guarantee of certainty regarding the status of witnesses of collaborating perpetrators. Such law enforcement is certainly not fair for criminal offenders who cooperate with law enforcement officials because there is no clarity about their status as justice collaborators and there are no definite criteria regarding the main perpetrators. This even tends to violate the human rights of the perpetrators of crime because with his actions to cooperate with law enforcement officials have placed himself and his family in a vulnerable position to be intimidated or get attacks from those who feel aggrieved by the witnesses 'witness' information. For example, in the case of corruption in the procurement of electronic National Identification cards, the public prosecutor has appointed Irman and Sugiharto as justice collaborators but the case review judge at the appeal and cassation level refused to grant them justice collaborator status. The two defendants were even sentenced to prison terms which were far higher than the demands filed by the public prosecutor at the KPK.

Law enforcement practices that occur relating to justice collaborator will certainly be very detrimental to law enforcement officials themselves. There is a difference of opinion between the public prosecutor and the panel of judges examining the case because there are no standard criteria in the legislation concerning the main actors. Investigators and public prosecutors are those who 
know about the involvement of suspects or defendants in uncovering a criminal act while the panel of judges examining the case only knows the facts contained in the investigation case file and additional facts showcased in the trial. Thus, there is a tendency to reject the status assigned to the defendant as a justice collaborator if there are no standard criteria regarding justice collaborator. Thus, in the context of legal reform on the protection of witnesses of collaborating actors, one of the important aspects that needs to be considered and regulated is the criteria of the main actors. This is to prevent differences of opinion between the public prosecutor and the panel of judges examining the case regarding the status and position of the witnesses who cooperated.

In addition, justice collaborator should be regulated in a separate law because it has different characteristics from the protection of witnesses and victims. Justice collaborator is an actor who cooperates with law enforcers through his testimony to expose a crime while witnesses and victims are parties who know about a crime or experienced the consequences of a criminal offense. In addition, justice collaborator is not intended for all types of criminal acts but only for serious or organized crime.

\section{Legal Protection for Justice Collaborator}

The function of law as protection of human interests are to ensure that human interests are protected. Thus, such laws must also be implemented. Based on this statement, the law can provide protection for human interests if the law is formed on the basis of legal certainty, justice and expediency. If the law is not formed based on the three objectives of the law, the law cannot provide legal protection for human interests. The procedure for establishing this Justice Collaborator in the Witness and Victim Protection Act is not strict because it only stipulates that obtaining an award in the form of criminal conviction, LPSK provides a written recommendation to the public prosecutor to be included in his claim to the judge. The provisions in the LPSK Law do not have strong legal reasons because those who can judge whether an offender has cooperated with investigators or public prosecutors to dismantle a serious or organized crime is the investigator or the public prosecutor himself. 
The LPSK's understanding of handling a case is not exhaustive and comprehensive so it is irrelevant if the public prosecutor has to wait for a recommendation from LPSK to give an award to justice collaborators. Declaring the status of a Justice Collaborator should not wait for a recommendation from LPSK. The public prosecutor in assessing a suspect or defendant can qualify as a justice collaborator should refer to the conditions that have been determined in the legislation namely to have paid replacement money, paid a criminal fine and also served the sentence for a basic crime. The perpetrators who will be determined as Justice Collaborators are the main perpetrators in a different criminal act that the one they are testifying for. This is in accordance with the contents of Article 28 paragraph (2) letter c which states that the witnesses of the perpetrators or the Justice Collaborator can only be given to not as the main perpetrators in the criminal acts they disclose.

The issuance of Justice Collaborator which was only published after the judge's verdict and was issued for those perpetrators of a single criminal act would certainly make the legal protection regulated in Article 10A of the PSK Law not be able to run optimally. Consideration whether or not the request is granted depends on a number of things, including: if the suspect wants to cooperate with the KPK investigator, acknowledges the suspicion, and is willing to provide information related to the case that ensnared him. After this submission, it will then be examined by the investigation team and submitted to the higher-ups. Afterwards, the KPK Leaders will decide whether or not the application is accepted. The judge is not bound by the assessment given by the KPK to a defendant. This potential difference in opinions must be immediately solved in order to create legal certainty for the suspect or defendant in collaboration with law enforcement officials.

One form of compensation or reward for witnesses working together in the laws and regulations in Indonesia is the special treatment in the administrative side of criminal cases. Special administrative treatment in the settlement of criminal cases is only limited to the detention detention, the separation of case files and the mechanism for providing information. Some actions that are considered as a form of special handling in the Law on the Protection of Witnesses and Victims above 
should not have specificity because such law enforcement practices are already commonly practiced by law enforcement officials. Law enforcement officials in carrying out detention, segregation of case files and the mechanism for providing information do not depend on the status of a person whether as a justice collaborator or not but this is related more to the technical handling of the case. Thus, the concept of special handling of justice collaborator must truly contain specificity in the future so that it is worth mentioning as a form of appreciation.

As for the special treatment that can be applied in the future, it is not limited to the detention detention, the separation of case files and the mechanism for providing information but includes perhaps a different examination method of cases. Examination of different cases of candidates for justice collaborator implies that the examination of cases does not have to follow generally applicable procedural law. Special handling through examination of different cases will never be realized because the mechanism of determining justice collaborator in the applicable laws and regulations has yet to be clarified, in regards to when and who is authorized to determine it. For example, if the public prosecutor states that the defendant is a justice collaborator, but the judge believes that there will be legal uncertainty regarding the defendant's right after being convicted to obtain remission. Therefore, in order to prevent two different attitudes among law enforcers, different case handling mechanisms must be established between witnesses of the perpetrators who collaborate with other actors.

Determination of an offender to be a justice collaborator is related to proof of obligation. Based on Article 66 of the Criminal Procedure Code, the suspect or defendant is not burdened with evidentiary obligations so that a contrario who has proof of liability is a public prosecutor except for corruption related to assets as referred to in Article 37 A paragraph (1) of the PTPK Law and the crime of money laundering as regulated in Article 77 and Article 78 of the TPPU Law. With reference to Article 66 of the Criminal Procedure Code, the person who has the capacity to judge whether an offender has made a major contribution in uncovering a criminal offense is a public prosecutor charged with the obligation to 
prove the crime. In this connection, if a suspect has submitted a request as a justice collaborator, the investigator must submit the request to the public prosecutor. The public prosecutor will judge whether the suspect is appropriate to be determined as a justice collaborator.

Bearing in mind the practice of law enforcement in Indonesia, where judges are not bound by the opinions of public prosecutors as outlined in the demands, a special criminal justice system must be established in handling justice collaborator cases. The guilty plea is one of the conditions if the witnesses want to submit an application as a justice collaborator. Guilty confession is a legal practice that is commonly applied in Anglo-Saxon countries through plea bargaining mechanism. In the United States legal system, the process or mechanism of plea bargaining begins after going through conference meetings which may be more than one meeting, the accused may declare guilty (plead guility) or plead not guilty (plead not guilty). ${ }^{6}$ The Plea bargaining mechanism is carried out after an offer from the Public Prosecutor so that the perpetrator acknowledges his crime and if the accused accepts an offer to plead guilty, in another trial specifically examining the evidence, the judge (without a jury) immediately drops the criminal by remembering the factors that are showcased in the proceedings. ${ }^{7}$ Judges in deciding cases are not bound to believe the guilty plea of the perpetrators of the crime as stated by Peter Charleton and Paul Anthony Mc. Dermott BL. However, the Judge is required not to impose a forced verdict, a statement regarding a guilty plea is considered to be able to lead to a verdict but if there is an innocent statement, the judge does not immediately decide because it can be considered as undue pressure on the defendant and will result in depriving someone of freedom is a choice. "Plea bargaining is a negotiated agreement between a prosecutors

\footnotetext{
6 Andi Hamzah dan RM. Surachman, Pre-Trial Justice Discretionary Justice Dalam KUHAP Beberapa Negara (Sinar Grafika 2014).[151].

7 ibid.

8 Aby Maulana, 'Konsep Pengakuan Bersalah Terdakwa Pada Jalur Khusus Menurut RUU KUHAP Dan Perbandingannya Dengan Praktek Plea Bargaining Di Beberapa Negara' (2014) 1 Jurnal Hukum Straftrechts.[43].;Peter Charleton SC. and Paul Anthony Mc. Dermott BL, Constitutional Implicatons of Plea Bargaining (Bar Review 2000).[477].
} 
and a criminal defendant whereby the defendant pleads guilty to lesse offense or to one of multiple charges in exchange for some concession by the prosecutor, more lenient sentence or dismissal of the other charges". ${ }^{9}$

Plea bargaining is the formation of a negotiating agreement between the public prosecutor and the defendant in which the defendant pleaded guilty to a certain crime or for more than one charge and for the confession the public prosecutor will provide rewards in the form of light sentences or release of charges for other crimes. Timothy Lynch elaborates that:

"Plea bargaining consists of an agreement (formal or informal) between the defendant and the prosecutor. The prosecutor typically agrees to a reduced prison sentence in return for the defendant's waiver of his constitusional right against non self incrimination and his right to trial". ${ }^{10}$

In principle, plea bargaining is an attempt to settle a criminal case by encouraging the perpetrators of a criminal act to acknowledge their actions in exchange for their charges to be reduced.

Plea bargaining, in the English and Wales legal system, is interpreted as one of the methods that is mainly used by prosecutors to secure the testimony of someone accused of a crime against conspiracy that has been charged with a more serious crime. ${ }^{11}$ Verdun-Jones and Hatch argued that no doubt, Canadian judicial members have now accepted the fact that bargaining requests play an important role in the efficient administration of justice and have been defended by embracing punitive policies that indirectly influence the agreements formed by the Public Prosecutor and Law advisor. The criminal justice system that uses the plea bargaining approach can be applied in order to provide legal protection to justice collaborators. Speeding up the process of determining criminal sanctions for justice collaborators is a form of legal certainty for justice collaborators of the fulfillment of their rights as compensation for their involvement in disclosing extraordinary criminal acts.

\footnotetext{
9 Joseph R. Nolan, Black's Law Dictionary With Pronounciations (6th edn, St Paul Minn West Group 1990).[1152].

10 Timothy Lynch, The Case Against Plea Bargaining (Cato Institute Project on Criminal Justice 2003).[1].

${ }^{11}$ Aby Maulana (n 8).[56].
} 
The criminal justice system that uses the plea bargaining approach for justice collaborators is the right choice as a form of special treatment because there is no need for procedural criminal proceedings in general. Recognition from justice collaborator is sufficiently used as a basis for bringing down a criminal and justice collaborator will be more flexible in providing information for the purposes of disclosing extraordinary crimes. The criminal justice system that uses the plea bargaining approach for justice collaborator is in line with the principle of quick, simple and low cost of justice. By using the mechanism of plea bargaining approach for justice collaborator, differences of opinion between the public prosecutor and the judge can be minimized so that there is a guarantee of legal certainty for the witnesses of the collaborating actors. The legal protection mentioned above is in addition to the forms of protection of the Justice Collaborator, which has been regulated in Indonesian laws and regulations.

In addition to regulating the process of determining justice collaborator, the criteria or characteristics of the main actors are important elements in determining justice collaborator and must be clearly regulated in the legislation. Determining the criteria of the main actors are one of the main problems often encountered in the determination of justice collaborator. Based on the provisions of Article 4 of the Joint Regulations, the conditions for obtaining protection as witnesses of cooperating actors are:

a. Criminal acts that have been uncovered such as serious crimes and/or organized crimes;

b. Provide significant statements that are relevant and reliable to uncover a serious crimes and/or organized crimes;

c. No the main perpetrator of the acts uncovered;

d. The willingness to return an amount of assets that is obtained from the criminal acts invoked, provided by an official written statement; and

e. The existence of a real threat or concern of threat, pressure, both physically and/ or psychologically towards the individual that is cooperating or his/her family provided that the crime is uncovered in its truest light.

Some regulations have prohibited the establishment of justice collaborators as being the main actor, but none of these rules govern the understanding or criteria of non-main actors. The term main actor is a new term in criminal law that arises 
after the emergence of justice collaborator in the disclosure of serious or organized crime. In addition, statutory regulations also do not specify whether the main perpetrators in serious or organized crime can be more than one. When referring to several court decisions that refuse to grant justice collaborator status to a defendant, the main perpetrator may be more than one person as in the case of the procurement of electronic National Identification cards where the panel of judges examining the defendants Irman, Sugiharto and Andi Narogong, as the main perpetrators in that act of corruption are more than one main actor. The existence of several actors who are determined as the main actors should be contrary to the meaning of the word "main" itself. The main meaning in a large Indonesian dictionary is the best, number one, very good or better than others. ${ }^{12}$ Based on the main understanding, the main offender should only be one person, the most powerful or most influential person or the most decisive in the occurrence of a serious or organized crime. Thus, the main actors in a serious or organized crime is only one person, namely the person most responsible in relation to the power or influence or authority to determine policies or decisions so that a serious or organized crime occurs.

The categorization of the perpetrators of criminal acts in criminal law which has been known for a long time is related to the teachings of inclusion regulated in Article 55 of the Criminal Code. There are several types of criminal acts based on the provisions of Article 55 of the Criminal Code and Article 56 of the Criminal Code, namely:

1. Those who have committed criminal acts.

2. Those who ordered a person to do a criminal act.

3. Those involved in assisting a criminal act.

4. Those who suggest another person to do a criminal act.

5. Those who provide help, tools, opportunities or explanations to a criminal act.

The main perpetrators of a serious or organized crime should be determined based on the type of perpetrators of the crime in the teachings of inclusion and assistance above. Perpetrators who certainly cannot be categorized as the main

${ }^{12}$ Kamus Besar Bahasa Indonesia (KBBI), 'No Title' $<$ https://kbbi.web.id/utama $>$ accessed 12 October 2018. 
perpetrators are those who provide assistance, facilities, opportunities or information to commit a crime because their role is limited to assisting serious or organized crime. R. Soesilo stated and explained the capacity of the perpetrators of criminal offenses in criminal cases are of the following: ${ }^{13}$

a) A person (pleger) that has unilaterally and single-handedly executed or fulfilled the elements of a criminal act. In this criminal act must be done under his/her official capacity as a civil servant.

b) A person that directs another person (doen pleger) in which in this case, there must be at least two people the one directing (doen pleger) and the one directed (pleger). Thus this is not the person who directly commits the crime but has proven to direct another to do such crimes, even though by law he is seen as the person who directly commits such crimes.

c) A person who provides assistance in the criminal act (medepleger), providing assistance means to partake in an element of the criminal act. A minimum of two persons, such as the person who commits the crime (pleger) and the person who assists (medepleger) a criminal act. Based on this, both persons are committing the wrongful act thus fulfilling the required elements.

Didik Endro Purwoleksono argued that people who commit crimes have two meanings, namely every person who commits an act that is prohibited by law and every person who does something that causes an effect which is prohibited by law. ${ }^{14}$ A person who commits a criminal act under the existence of a suggestion or persuasion should be designated as the main actor in this crime, especially in cases of serious or organized crime. Furthermore, those who order or are called middelijke daderschap or actions with intermediaries can mean someone who wishes to commit a crime, does not do it himself, but tells someone else to do it. The will of the person directing another person to commit a crime is a fundamental element in proving this type of main act. Based on Memorie van Toelichting (MvT),

\footnotetext{
${ }^{13}$ R. Soesilo, Kitab Undang-Undang Hukum Pidana (KUHP) Serta Komentar-Komentarnya (Politea 1994).[56].

${ }^{14}$ Didik Endro Purwoleksono, Hukum Pidana (Airlangga University Press 2014).[59].
} 
the perpetrator is not only the person who commits a criminal act directly but can also a person who commits such crimes through another, using them as a tool for his will i.e if the directed person is persuaded due to his/her ignorance, a mistake or error that is intentionally inflicted on him or because of the existence of threat or violence that prevents his free will. If this person turns out to act without deliberate intent or purposeful negligence, he/she can be held liable for criminal liability. ${ }^{15}$ In other words, the person who directed another person to commit a criminal act can be held liable if it is proven that the directed person was indeed doing the criminal act outside of his/her own will.

Furthermore, regarding those who participate in committing criminal acts. Participating in committing a criminal act is equivalent to agreeing with others to make plans to commit a criminal act. ${ }^{16}$ The agreement referred to in the meaning of "taking part in doing" must also be seen as a form of the realization of the intention to carry out a criminal act, and the will or agreement formed must be independent.

Independence in making agreements means free from any form of intervention or intervention from any party. People who participate in criminal acts have the same position in the occurrence of criminal acts because criminal offenses are carried out based on a joint agreement. The position of the people who participated also carried out on an equal basis based on power, authority and decision making so that when correlated to the topic justice collaborator, all participating actors are considered as main actors. However, with regard to serious and organized crime, it is certain that the most powerful or most influential or decisive person in the occurrence of serious or organized crime is based on the characteristics of the criminal acts which forces the existence of the most powerful or most influential or most decisive person in the event of a serious or organized crime.

People who advocate or persuade and those who carry out these recommendations or persuasions can both be convicted upon the existence of an error. The conditional persuasion is intentional in order to persuade others to

\footnotetext{
15 ibid.

${ }^{16}$ D. Schaffmeister,[et., al], Hukum Pidana (Penerjemah: J.E. Sahetapy ed, Liberty 2011).[249].
} 
commit a crime, the intentional persuasion must be evident, the person who is moved to carry out the criminal act and the person who intentionally persuades must be held liable for criminal liability. People who persuade others to commit a crime are to be the main perpetrators in a serious or organized crime because those who persuade are those who have the ability to provide rewards and/or promises, means or opportunities or information to another person. This persuasion can also be complemented with a form of abuse of authority, violence, threat and craftiness. In addition, the person who is able to persuade has a very important and prominent role in the occurrence of a crime. Thus, they should be qualified as the main offender. Regarding the role of the perpetrators in the criminal act process as the basis for establishing the main perpetrators, the judges in the Irman and Sugiharto case, highlighted the fact that the parties played an important role in the stages of budget planning, stages of job auctions and stages of implementing the E-KTP project. These were the grounds for their establishment as the main perpetrators.

Based on the aforementioned explanations, the criteria to assert whether or a person is the main perpetrator for a serious crime or organized crime is:

a. A person that persuades or uses others to commit an organized crime;

b. A person that suggests or tricks another person to commit a serious crime or organized crime. The person who provokes this suggestion is usually a person with substantial economic capabilities which allows him/her to collaborate with the parties and provide a reward to the people persuaded. This could also be a person with power and influence as well as authority to create policies or decisions in the process of the serious crime or organized crime. This person could also be someone who can stop the occurring of a serious crime or organized crime but instead chooses to allow it;

c. A person that obtains aid from another perpetrator to conduct organized crime.

Based on the teachings of the above, then what is interpreted as the main actor that will be granted the status of justice collaborator can be one person or more than one person. In the context of justice collaborator, the only legal subject that can be a justice collaborator is a person, individually or composed of several 
people. In the perspective of the ius constituendum, strict rules are needed relating to the mechanism for determining a person to become a justice collaborator, so that there are no differences in views between law enforcers in establishing one's position as a justice collaborator; it is necessary to formulate explicitly what types of crime are required by the existence of justice collaborator; forms of protection both physical and psychological for justice collaborator and his/her family, special handling during undergoing legal process, as well as awards in the form of the amount of sentence relief obtained for his contribution as justice collaborator.

\section{Conclusion}

Legal protection for justice collaborators is not limited to personal protection, but includes the physical and psychological protection of their families. Allegedly criminal acts that require the participation of justice collaborators are crimes categorized as extraordinary crimes which are carried out in an organized and transnational manner. One form of appreciation that can be given to justice collaborators is special handling of criminal cases. Special forms of handling criminal justice collaborator cases in the criminal justice system can utilize the plea bargaining approach as legal protection for justice collaborators. Accelerating the process of determining criminal sanctions for justice collaborators is a form of legal certainty for justice collaborators, in regard to the fulfillment of their rights as a tribute to their involvement in the disclosure of extraordinary criminal acts. The criminal justice system that uses the plea bargaining approach for justice collaborators is the right choice as a form of special treatment because there is no need for conventional criminal procedural law in general.

\section{Bibliography}

Aby Maulana, 'Konsep Pengakuan Bersalah Terdakwa Pada Jalur Khusus Menurut RUU KUHAP Dan Perbandingannya Dengan Praktek Plea Bargaining Di Beberapa Negara' (2014) 1 Jurnal Hukum Straftrechts.

Agus Priono, 'Penerapan Teori Penafsiran Hukum Oleh Hakim Sebagai Upaya Perlindungan Hukum Terhadap Notaris (Studi Atas Putusan Hakim Terhadap 
Tindak Pidana Pemalsuan Akta Otentik)' (2017) v Jurnal Pasca Sarjana Hukum UNS.

Andi Hamzah dan RM. Surachman, Pre-Trial Justice Discretionary Justice Dalam KUHAP Beberapa Negara (Sinar Grafika 2014).

Bintara Sura Priambada, 'Eksistensi KPK Dalam Memberantas Tindak Pidana Korupsi' (2017) VI Lex Crimen <https://media.neliti.com/media/ publications/170253-ID-eksistensi-kpk-dalam-memberantas-tindak.pdf $>$.

D. Schaffmeister,[et.,al]. Hukum Pidana (Penerjemah: J.E. Sahetapy ed, Liberty 2011).

Didik Endro Purwoleksono, Hukum Pidana (Airlangga University Press 2014)

Joseph R. Nolan, Black's Law Dictionary With Pronounciations (6th edn, St Paul Minn West Group 1990).

Kamus Besar Bahasa Indonesia (KBBI), 'No Title' <https://kbbi.web.id/utama $>$ accessed 12 October 2018.

Koran Sindo, 'Hukuman Untuk Agus Condro Disesalkan' (Indonesia Corruptionn Watch, 2011) <https://antikorupsi.org/id/news/hukuman-untuk-agus-condrodisesalkan> accessed 27 August 2019.

Peter Charleton SC. and Paul Anthony Mc. Dermott BL, Constitutional Implicatons of Plea Bargaining (Bar Review 2000).

R. Soesilo, Kitab Undang-Undang Hukum Pidana (KUHP) Serta KomentarKomentarnya (Politea 1994).

Rosmiyati Dewi Kandi, 'Syarat "Justice Collaborator" Jadi Kendala Dapatkan Remisi' (CNN Indonesia, 2016) <https://www.cnnindonesia.com/ nasional/20160427193723-12-127069/syarat-justice-collaborator-jadikendala-dapatkan-remisi?> accessed 30 August 2019.

Supriadi Widodo Eddyono, Perlindungan Saksi Dan Korban: Catatan Atas Pengalaman Pengadilan HAM Ad Hoc Kasus Pelanggaran HAM Berat Di Timor Timur (ELSAM 2005).

Timothy Lynch, The Case Against Plea Bargaining (Cato Institute Project on Criminal Justice 2003).

HOW TO CITE: Hidayatullah, 'Legal Protection for Justice Collaborators in Indonesia’s Criminal Judiciary System’ (2020) 35 Yuridika. 